\title{
ROOTS OF CONTEMPORARY IRANIAN POLITICS: AN INTERPRETATION
}

\author{
A. Reza SHEIKHOLESLAMI*
}

\section{Introduction:}

At the outset of 1978 , Iran was still a case study of a stable modernizing autocracy. By November of the same year, however, the Shah's apology to the nation, on the public radio, for the oppression and corruption that had been inflicted on the Iranians, indicated that the end had come. In February, 1979 , the regime collapsed. The quick surrender of the regime in the face of seemingly sustained economic growth, powerful military structure, and growing international posture questions the validity of many theories of revolution as well as our understanding of Iran. Considering that guerrilla activities had been reduced to few isolated cases and in fact by 1977, guerrilla organizations had become infiltrated, the fall of the monarch to the Revolution is even more enigmatic.

Corruption, oppression and rapid modernization ore often identified as the causes of the Revolution. Had any $f$ these factors, or their combinations, been sufficient to bring about a revolution, one might have expected revolutions in a host of other countries before it took place in Iran. Nor would the dependency of a system within the international arena, as some argue, necessarily lead to a revolution. ${ }^{1}$ Dependency often

* This paper is partly based on interviews and research the author carried out in Iran during the Summer and Fall, 1978, as a Senior Fellow at the Iran Planning Center.

1 Thede, Skocpol presents this hypothesis in her States and Social Revolutions (Cambridge, 1979), and Barry Rubin, Paved With Goo!l Intentions: The American Experience in Iran, (New York, 1980) identifies the dependent relationship which Iran maintained with 
strengthens the mechanism of the rule of the dependent ruling class. The extra-territorial support may adversely affect the system's legitimacy, but at the same time it sets the balance of power in favor of the dependent rulers. Dependent systems are frequently illegitimate to begin with, and their deepndence ensures their continuation in the face of the loss of legitimacy. Their eventual fall is, consequently, not brought about by their dependence. Rather, it is an indication of the unwillingness or inability of the extra-territorial support to maintain the favorable balance of power.

Most specialists on Iran, as well as the present power holders in Iran, have identified yet another, albeit, a uniqus factor, as the force behind the Revolution. Shiism, a particular Islamic belief pattern, prevalent in Iran only, is singled out as the precipitating element of the Revolution. ${ }^{3}$ It is argued that Shiism, in contrast to other Islamic schools, withholds legitimacy from the political authorities, identifies rulers as usurpcrs, and thus it is fundamentally a revolutionary belief system. It is further argued that Shiism has an organization format, in the form of clergy, and is financially independent of the state.

In fact, the 40,000 or so mosques in Iran played an important role as a cellular structure within which the populace gathered with impunity, where information was disseminated, and the

the United States as a major contributing factor towards the making of the Revolution. This explanation, also, serves the ideologica! position of the present Iranian government which at times has justificd the Revolution ir terms of opposition to the former system: dependence on the U.S.

2 In this regard the Shah's comments in Muhammad Reza Pahlai. Answer to History (New York, 1979), pp. 112-120, regarding his inability to act decisively because he was uncertain of Americin support is instructive. In this vein, one may argue, therefore, that the Revolution succeeded not because of dependence, but because of the absence of commitment by a superpower to stand firm. $y$ behind a dependent one.

${ }^{3}$ The most scholarly ones ' $\mathrm{n}$ this genre are Shahrough Akhavi, Religion and Politics in Contemporary Iran, Clergy-State Relations in iilt. Pahlavi. Period, (Albany. 1980); Michael M. Fischer, Iran: Fron: Religious Dispute to Revolution, (Cambridge, 1980); Hamid Alge: "The Oppositional Role of the Ulama in Twentieth-Century Iran" in Nikki R. Keddie (ed.) Scholars, Saints, and Sufies (Berkeley, 1972) pp. 231-2s6. 
demonstrations were planned. The high clerical's social position in Iran has also depended on aloofness from the political authority. This in turn has been normally translated into greater trust manifested by the populace and a greater share of khoms, the religious tax, so far voluntarily paid to any clergyman. Ayatollah Khomaini apparently received more in voluntary donations than the Shah': government collected in taxes during the year which preceded the Revolution.

The religious explanation, limited to the Iranian situation is much tco narrow to be of explanatory value to the general understanding of the revolutionary phenomenon. Revlutions have occurred in places where Shiism has been absent. Conversely, Shiism has been popular in Iran many centuries without necessarily being revolutionary. While the Shii clergy has often played an anti-imperialist role their attempts have been historically aimed at retreating the status quo ante, rather than restructuring the society.

This paper argues that the Iranian Revolution can be properly understood in the context of the historical conflict between the center and the periphery. The central states has been generally personified in the form of a person, i.e. the ruler. The periphery consisted of those not affiliated with the ruler as members of his household. The perceiver inabilicy of the ruler to guard the interests of the periphery against extraterritorial powers and his demands for the universal subjection to his rule within his kingdom set the stage for conflict. What makes the Iranian Revolution more radical than its historical antecedents is a class dimension was added to the earlier causes of conflict. The overlapping of center-versus-periphery tension with that of class conflict transformed the Iranian Revolution from a simple traditional conflict for power into a social revolution which demandca the complete re-structuring of the society. The survival of the center-periphery tension, on the cther hand, has colored the ideology and direction of the change.

\section{Cycles of Modem Iranian History:}

Up to the end of the 18th century, the Shii thought followed the Akhbari school in which all authority was presumed to belong to the Hidden Imam, a messiah. In his absence no 
one could stt claim to his sacred or secular authority. ${ }^{4}$ The negation of the legitimacy of the actual authorities was not necessarily revolutionary. In fact, it led to political quietism as it was pointless to replace one set of rulers for another who would be equally illegitimate. In the absense of any mode of legitimation, governments remained military phenomena. Based on actual power alone, they were necessarily unstable, as power relations fluctuate periodically.

In contrast to the presumed tradition of monarchy in Iran, most dynasties during the Islamic period have been short-lived and most have been Turkish, depending on military force and the populace's preference for order to disorder. They rose and fell independent of a religious structure, or populace's will, much in the Marxian Asiatic type. ${ }^{5}$ Division of the society into cellular semi-autonomous communities which contained all the conditions for production and reproduction and consequently the absence of class structure did not give the society the mechanism of supporting or opposing the government. The inherent paralysis of the society gave the appearance that the state was omnipotent. Faced with each isolated community, the state was despotic. Lacking social support, the state often fell to other forces without much change in the lives of ordinary subjects. The history of Islamic Iran has been a history of political instability. The present chaos is not an aberration. Rather, it is a new phase of conflict in the Iranian society.

In the beginning of the Nineteenth Century two developments, one ideational and the other one objective, brought about an integrative process in Iran and provided the society with mechanisms to oppose the state.

1) The Usuli school, which became dominant in the Shii thought in the 19th century, enjoined the Shiites to follow the teachings of a living theologian. Consequently, a new group

4 See Muhammad Husain Tabatabai, Shiite Islam, transiated by Seyład Hossein Nasr, (Albany, 1975).

3 See Karl Marx, Pre-Crpitalist Economic Formations, translated by Jack Cohen, (New Yor:. 1965); Karl Marx, On Colonialism and Modernization, edited by Shlomo Avineri, (Garden City, New Yo:k 1969); Zrnest Mandel, Tlie Formations of the Economic Thou sht of Karl Marx, (New York, 1971), pp. 116-139; Umberto Melotti, Marx and the Third World, trinslated by Pat Ransford, (London, 197i) 
emerged which closely resembles the clergy in the Christendom both functionally and institutionally. ${ }^{6}$ As deputies to the Imam, they were collectively the leaders of the Shii community and the embcdiment and the routinization of the Imam's charisma. As Iran was the only Shiite country, the clergy's leadership of the religious community developed nationalistic and political ranifications, as well. During the Nineteenth Century, when imperialism was increasingly dividing up the world, the clergy was called upon time and again to defend the Shii nation, i.e. Iran.

2) Political centralization, expansion of monetary relations, and increases in commodity exchange and further communication led to the development and differentiation of the bourgeoisie in an embryonic form. In the Nineteenth Century the penetration of the Iranian economy by the imperial powers, and the growing integration of the former within the world market system during the same period, adversely affected the nascent bourgeoisie. More specifically, the mercantile bourgeoisie and the productive national bourgeoisie, found their activities curtailed and their productions not competitive with the cheap and machine made European commodities. The state at the same time became increasingly dependent on cash as a consequencs of its integration in the world market system and the extension of monetary relations. Thus, not only was the state reluctant to accept taxes in kind, but it continuously attempted to ameliorate the economic hardships by granting monopoly rights for immediate cash. ${ }^{7}$ These measures burdened the peasantry, on

c Joseph Eliash, in "Misconceptions Regarding the Juridicial Status of the Iranian "Ulamac," Internatioonal Journal of Middle Easitur. Studies, Vol. 10, No. 1, February 1979, pp. 9-25, considers the deves 'p. ment of the clergy in Shiism as an abberation lacking juridiri:1 foundation. For a more positive study of the ulama see Famid Algar. State and Religion in Tran, 1785-1906: The Role of Ulama in Q $Q_{1 ; i}$ Period, (Berkeley, 1969).

7 See Faridum Adamiyat énd Homa Natiq, (eds.), Afkar-i litimaci va Siyasi ve Iqtisadi, (in Persian). (Tehran, 1977) for the study vi the changing economic relations under the impact of the West. I or a short but insightful view of the period under study her esee Nilki Keddie, "The Iranian Power Structure and Social Change, 1800 1969 An Overview." International Journal of Middle East Studies, Vol. 8, 1977. 
the one hand, and the bourgeoisie on the other. The peasantry itomized and atavistic could not resist. The bourgeoisie did.

The Reuter Concession of 1872 in which Nasir al-Din Shah, 1848-1896, granted almost all of his country as a concession to a foreign national and Regie Concession of 1891-1892 in which te tobacco trade was given as a monopoly to a British Subject are cases in point. ${ }^{a}$ In each case, the monarch curtailed his subjects' economic sphere in return for ready cash. In each case, the monarch was opposed by an alliance of the clergy, speaking for the people against government's excesses, and the bourgeoisie whose economic interests were threatened by the Western penetration.

This pattern of alliance repeated itself during the Constitutional Revolution, 1905-1909, where both the clergy and the bourgeoisie attempted to set limits on the arbitrariness of the king's rule. The Constitutional Revolution did not aim ai establishing democracy. Rather, it was intended to divide political authority along traditional lines. The church and the bourgeoisie as well as the king were to share power. The composition of the first Parliament, divided into three estates ,the nobles, the merchants and guild masters and the ulama, attest, to this.

Such delicate balance could not be easily maintained. The full impact of imperialism in the form of division of Iran between Russia and Britain into spheres of influence in 1907, and later the Bolshevik threat, and the Anglo-Iranian Agreement of 1919 , which practically attempted to turn Iran into a British protectorate, made the continuation of the power configuration in Iran impossible. The chaotic Iranian situation and the development of republics along the Soviet line, convinced the British as well as many of the Iranians of the necessity of setting up a strong central government. The Coup of 1921 which subsequently brought the Pahlavis to power, 1925-1979, marked

${ }^{8}$ For more information oil monopolies granted to foreigners see Firuz Kazemzadeh. Britain asd Russia in Iran, (New Haven, 1968' and Nikki Keddie, Religion and Rebellion in Iran, The Iranian Tubacco Protest of 1891-1892, (London, 1966). For a similar situation see Samit Amin, The Arab Nation: Nationalism and Class Strugs'e ilon. don, 1978). 
the emergence of the state, embodied in the person of the king, as the centripetal force in the Iranian politics. ${ }^{9}$

The pattern of conflict between the center and the periphery has been endemic to Iranian history. The success of the center is marked by its penetration of the periphery and attempt at its complete subjugation. Overextension of the center, in addition to its weak organizational base, and its inability to legitimate itself, have historically led to the resurgence of the peripheral forces and defeat of the center. Given the disarray of the peripheral forces, and their often atavistic nature, chaos became the predominant form of political behavior, which in turn prepared the way for the emergence of a despotic cenier.

The predominance of the center during the first phase of the Pahlavi rule came to an end when Riza Shah abidcated in 1941. From 1941 until 1953 the peripheral forces, consisting of the landowners, tribal leaders, the clergy, and the bourgeoisie vied for power. The intervention of another world power, the U.S. and the general disaffection helped Muhammed Riza Shah, 1941-1979, to assert his authority in 1953 and thus the cycle of despotism began. The clergy, concerned about the threat of communism, suspicious of extensive politicization of the population, had broken ranks with Muhammed Musaddiq, the liberalnationalist prime minister, 1951-1953, before the coup toppled him.

The last two cycles of peripheral dominance, the Constitutional Period and Musaddiq era, were the cycles in which liberal ideology was followed by the declaration of Iran's dependence on imperial powers and then the rise of Riza Shah, 1526-1941. The liberal government of Musaddiq was followed by despotism and growing American influence. The defeats of both liberal efforts have created questions regarding not only the efficacy but for that matter the legitimacy of liberalism which presently color the Iranian Revolution and are used to legitimize its illiberal tendencies.

$\sqrt{9}$ For the analysis of thi speriod and the general features oi the Iranian economy and society up to 1978 see Nikki R. Keddre, Roots of Revolution: An Interpretive History of Modern Iran, (New Hilven, 1981) and Homa Katouzian, The Political Economy of Modcin Iran: Despotism and Pseudo-Modernism (London, 1981). 


\begin{tabular}{|c|c|}
\hline Cycle & \multicolumn{1}{c|}{ Characteristics } \\
\hline 1905-1921 & $\begin{array}{l}\text { Peripheral hegemony: } \\
\text { Constitusional Revolution: assertion of localistic and } \\
\text { centripetal sentiments; inability of the centra! go- } \\
\text { vernment in applying rules; some libaralism but } \\
\text { mostly attempts towards maintenance of traditional } \\
\text { spheres of power; foreign invasion. }\end{array}$ \\
\hline 1921-1941 & $\begin{array}{l}\text { Central hegemony: } \\
\text { Riza Shah; establishment of modern communication, } \\
\text { burcaucracy, and military; extensive penetration of } \\
\text { society. }\end{array}$ \\
\hline 1941-1953 & $\begin{array}{l}\text { Peripheral hegemony: } \\
\text { Extensive liberalism; foreign occupation; nationalism; } \\
\text { re-asserticn of religious and tribal forces. }\end{array}$ \\
\hline Central hegemony: \\
The most complete penetration of the society by the \\
government in the Iranian history; personalism. des- \\
truction of conservative positions of leadership in \\
the periphery; transformation of the society into a \\
class one.
\end{tabular}

\section{The Revolution of 1978-79:}

The present regime in Iran is the third cycle of the peripheral upsurge in this century and was characterized at first by the participation of the same centrifugal social forces which put an end to the central authorities of the past: the national bourgeoisie, the clergy, the bureaucratic stratum, and the intelligentsia.

The present cycle, however, is different from its percursors in three ways. Firstly, it has managed to destroy the center so violently and successfully, that its chances for a comeback in the former style and composition are much reduced compared to the furmer cycles. Secondly, the traditional peripheral hie- 
rarchies which had maintained a symbiotic relation with the center, tribal chiefs, landowners, etc., were eradicated in the post-1953 developments. Their moderating influences which existed earlier do not exist any more. The co-existence which prevailed earlier between the center and the periphery during the latter's ascendency does not exist anymore, either. Thirdly, the Iranian class structure today is radically different from that of the earlier comparable cycles. The peasant structure has finally given to an urban one, where the majority are city dwellers and the cconomy is dominated by nonagrarian sectors. The similarity of the present cycle with the former ones is that chaos is the order of the day. The intensity of the chaos compared to the former cycles is paralleled by the intensity of the disaffection with the present regime and its increasing isolation.

The intensity of the Iranian Revolution has been partly due to the earlier elimination of the intermediary loci of power between the ruler and the populace. The simplification of the hierarchy of authority into a dichotomy intensified the conflict between the ruler and the ruled. Moreover, at no other period had the center penetrated the society so intensely. Not only. did the oil, a state monopoly, dominate the economy, but the state increasingly interfered in the daily lives of the people in the forms of new modes of regularization and establishment of controls. No modern state can escape such interventions. But the interventions of a personalistic state in the lives of its subjects is often dis-stabilizing in the long run.

Given the cyclical pattern of the past Iranian history, i.e., centralizing personal despotism, followed by peripheral resurrection, anarchy, and despotism again, the re-emergence of the centrifugal forces could have been anticipated. The elements which brought about the earlier cycles existed in 1978. The assumption of political stability under the Shah was therefore historically short-sighted. In addition to the forces which had historically operated in Iran, modern forces had come into existence which were fundamentally in contradiction to the prevailing political structure.

The Iranian political system until the fall of the Shah in 1979 was a patrimonial one where rulership was conceived as 
property belonging to a family. Office holders were members of the ruler's household. Patrimonial relations also permeated the society until 1963 when the land reform program undermined the authority of the agrarian lords, and the conservative religious opposition to the system was brutally put down in 1963. The mode of the government, however, in contradiction to the social change remained patrimonial. The facade of modernity only painted over the fact that Iran of 1978 was a personalistic state where the decisions were made arbitrarily in an increasingly complex society.

The often stated claim that the Shah modernized much too fast and society remained deeply traditional and the contradiction between modernization and the society's traditionalism brought about the Revolution is misleading. On the contrary, the structure of Iranian politics was frozen in its traditional shape, i.e., the state was anthropomorphized in form of a person. The suciety, nevertheless, was increasingly developing along class lines.

Between 1966 and 1976, the wage-labor system expanded rapidly at the expense of the non-wage system. The working class, those who sold their labor, became numerically the dominant class in 1976, accounting for $54.1 \%$ of the labor force. In 1966, they constituted only $48.4 \%$ of the work force. The relative sizes of the bourgeoisie, those who employed the labor of others, and the petty-bourgeoisie, those who were self- employed, actually declined respectively from 2.2 to 2.1 and from 49.3 to 43.8 . In short, within a decade Iran had developed the characteristics of a dominantly working class socicty.

The Iranian working class, however, was not an industrial proletariat. The majority worked in small shops which employed less than ten workers. Those who worked in industrial plants, emplcying ten or more workers accounted for only $5.3 \%$ of the work force. ${ }^{10}$

Consequently, the Shah's patrimonial regime had become anachronistic in a society which had developed an urban work-

10 The figures are based on Government of Iran, Statistical Ycarbook. 1969, Statistical Center of Iran. National Census of Populatin. and Housing, 1976, Total Country. 
ing class structure. At the same time, the industrial proletariat was much too small to become the vanguard of a radical social revolution. The leadersnip of the Revolution fell to the traditional working class whose concentration in urban centers gave them the necessary bases for organization solidarity and had numerical superiority. The Shah's Westernization was par. ticularly disturbing to the members of this class. Modern industry threatened their existence, just as the economic penetration of Iran by the imperialist forces, a century earlier, had threatened their predecessors. The petty bourgeoisie and the bourgeoisie were also being seriously threatened by the development of small but poweriul monopolist capitalists, who, utilizing a network of political connections, capital intensive industry, and modern technology, actually shifted the center of Iranian economy from the labyrinth of the bazaar to the boulevards of northern Tehran. The monopolist capitalists were closely associated with the Pahlavi family and supported the system. Their support, howeves, was not crucial due to their many contradictions within themselves and with the personalistic and arbitrary regime. Furthermore, as a class they depended on the system for the grants of monopoly rights. In other words, in contrast to Marxian analysis, monopolist capitalists existed because of the dynamics of the political factors rather than any economic factors. When the political rule weakened in the process of the Revolution, this class was not in a position to lend support to the system.

The industrial proletariat remainer apolitical until the fate of the regime was almost sealed. At the end of the summer of 1978 , the oil workers and electrical workers went on strike. The industrial proletariat employed in the private sector did not stop work until towards the end of 1978 when raw material became scarce. While the industrial proletariat could not support the patrimonial regime in the long run, as a labor aristocracy, its support for the Revolution was not whole-hearted. Since the Revolution, it has lost many privileges bestowed on it by the former regime. Profit-sharing regulations are discarded as they purportedly helped only few workers - those in large private industry. Workers in many plants in the private sector, Iran National, the largest automobile plant in Iran, for instance, are threatened with lock-outs. 
When the Shah's personal patrimonial rule weakened in the face of ricts and strikes, including those by the bureaucrats at the Ministry of Intcrior, charged with internal security of the country, the Shah formed an alliance with the military on November 5, 1978. While his rule had always relied on a military basis, the Shah had successfully refused to let the military play a rcle in the political decision-making process since 1953. The aliiance indicated the monarchy's weakness, but it also showed its fear of complete military take-over. ${ }^{11}$

When in power, the Shah had seen to it the military command was fragmented, united only in his person. Units werc disallowed from communicating with each other. Sectoral jealousies were encouraged and military intelligence was gathered by many organizations with overlapping spheres of authority. Consequently, the declaration of martial law and military government seemed almost as threatening to the Shah as the riots waged daily. The government of the generals was forced on the weakened monarch by the heads of the services in a concerted action which made the likelihood of complete military take-over even more ralistic. The Shah did his best to set controls on military actions against the riots and complete control of the ministries by the generals. Less than two weeks after the declaration of the military government, the civilians began to replace the generals in the cabinet. The military government was a farce. Posing no threat to the monarchy, it was also toolhless to defend it. The chances of the Shah's survival in November of 1978 were not good. The Shah's fear of the military made them worse. The trump card, i.e. the military, was drawn and then was partially pulled back and thus was wasted.

The continuation of strikes and riots and the inability of the military to respond to them, compelled the Shah to invite the National Front, Musaddiq's followers to share power with him. Shahpour Bakhtiar accepted the challange on December

\footnotetext{
"Much of this section dealing with events in Iran during the Revolution on the author's personal observations and interview in Iran between June 1973 to January 1979. For the chronology of events in Iran see Nicholas M. Nikazmerad, "A Chronological Survay up the Iranian Revolution, Iranian Stuoiies, Vol. XIII, Nos. 1.4, 198:. pp. 327-368.
} 
29, 1978. Immediately expelled by the Front, he was still the first premier since Musaddiq to represent the liberal bourgeoisie instead of merely being an extension of the Shah.

Bakhtiar's political reforms during his six-week tenure of office, such as the Shal's departure from the country, lifting of censorship, abolition of the secret police, and release of political prisoners further fueled the fury of the Revolution and convinced those who still needed convincing that the cause of the Shah was a lost one.

At each step during the Revolution the scope of politics became larger. 1978 began with politics being the exclusive realm of the Shah. In November, he was forced to share it with the military. In December he was forced to look towards the National Front whom he deeply despised. The troika of the monarcy, the military and a section of liberal bourgeoisie was not enough to tip the balance in favor of the Shah. On February 11, 179, the old structures of authority were defeated. The military submitted to the forces of the Revolution and a new alliance took over.

\section{Post-Revolutionary Iran:}

At the top the new system of authority was not very different from the one just replaced. The elements of the liberal bourgeoisie were ostensibly in charge of the government. Mahdi Bazargan formed a cabinet whose members were Bakhtiar's former associates. The new government attempted to reduce the goals of the Revolution to the abolition of the mnarchy which had already been achieved. They failed, however, to stop the Revolution and return to normal politics because the formal holders of powers, i.e. the liberal bourgeoisie, were not the vanguard of the Revolution. Lacking a solid social base in the Iranian scciety and having been suppressed by the Shah they did not have the resources and organizational ability to stop the further radicalization of the Revolution.

On more than one occasion, Bazargan declared that the Revolution was over and requested the return of the exparriated enterpreneurs and managers to Iran in order to continue their direction of the economy. Serious efforts were made to nor- 
malize the relations with the U.S. which until recently had supported the Shah. In short, the liberals' aim was to turn the Iranian Revolution into a bourgeois anti-absolutist one.

The liberal bourgeoisie was only formally in charge of the state. Conflict within its ranks weakened it even more, leading into further fragmentation of the National Front, shake-up of the cabinet, dismissal of the Director of the Netional Oil Company and Chief of the Staff. What proved to be fatal to the bourgeoisie was that the actual positions of power were controlled by the members of the petty-bourgeoisie. Small shopkeepers and lower-ranking clergy controlled the Revolutionary Guards, Committees, and Courts. None of these centers of power paid even lip service to the government. The premier was often informed of major decisions by listening to the radio. The Committees not only controlled and governed the city, but they gradually came to control the bureaucracy. also. They purged the bureaucrats whom they found undesirable and even arrested one minister.

The take-over of the American Embassy on November 4, 1979 on the pretext of the Shah's admission to the U.S. and Bazargan's meeting with Zbigniew Brzezinski, the American National Security Advisor, finally put an end to any doubts that the liberal bourgeoisie might be in control. A few elements of this class who had curried favor with the more radical pettybourgeoisie and the traditional working class, such as the former President Abu al-Hasan Beni-Sadr and the former Minister of Foreign Affairs, Sadiq Qutbzadih, were gradually to be discarded, as well.

The Revolution has so far primarily been the gift of the traditional working class and the petty-bourgeoisie. Consequently, it has little appreciation for modern industry and its social relations. It is symptomatic of the regime's orientation that atomic plants have been converted into silos. The penetration of Iran by the ivorld capitalist systems meant the anachronization of the traditicnal workers and the petty-bourgecisie. Consequently, the present Iranian regime, voicing the wishes of this class is xenophobic. Its appeals are only superficially supra-nationalist under the guise of Islamic solidarity. 
In fact, the latter is used, albeit unsuccessfully, and crudely, for intervention in the affairs of others and search for regional supremacy. The traditional working class is suspicious of the foreign and Marxist revolutionary formulae, but it reacts favorably to the formulations of its own aspirations presented by the clergy in Islamic forms.

The complete destruction of the ancient regime and the inherent and historical weakness of the liberal-bourgeoisie. have permitted the Revolution to become continuously more radicalized. When the revolutionary leadership is unable to exercise control, revolutions normally become more widespread. The Iranian Revolution was a spontaneous and leadersless revolution. The revolutionary elite which developed in th: process of revolution in China and elsewhere did not come into existence in Iran during the short period of uprising. The present ruling group, consisting of the clergy and their allies however, have become more experienced in organizing and the running of a government in the past three years. Their rule is nevertheless not insured, given their inability to respond to the economic problems and minorities' demands, on the one hand, and pressures from popular Islamic Mujahidins from the left, on the other. 